\title{
High frequency of IDH-1 mutation links glioneuronal tumors with neuropil-like islands to diffuse astrocytomas
}

\author{
Jason T. Huse $\cdot$ Khedoudja Nafa $\cdot$ Neerav Shukla $\cdot$ \\ Edward R. Kastenhuber • Ehud Lavi · Cyrus V. Hedvat • \\ Marc Ladanyi • Marc K. Rosenblum
}

Received: 6 June 2011/Revised: 30 June 2011/ Accepted: 30 June 2011/Published online: 14 July 2011

(C) The Author(s) 2011. This article is published with open access at Springerlink.com

The glioneuronal tumor with neuropil-like islands (GTNI) is an uncommon histopathological entity composed of diffuse astrocytic or oligoastrocytic elements interspersed with sharply delimited, micronodular loci of neuronal differentiation. Despite its initial description over 10 years ago [10], the lineage classification of GTNI remains speculative. The clinical features of GTNI, its infiltrative growth characteristics, typically dominating astroglial components, and frequent p53 expression, are all consistent with a fundamental linkage to the diffuse astrocytic tumor group. Supporting this notion are reports documenting, by comparative genomic hybridization, an astrocytoma-like profile of 7q21.1-qter gain and 9p21-pter loss in one case [8] and the absence of oligodendroglioma-associated $1 \mathrm{p} /$ $19 q$ deletions in a series assessed by polymerase chain reaction-based loss of heterozygosity analysis [3].

Point mutations in the isocitrate dehydrogenase enzymes, IDH1 and IDH2, are found in the majority of WHO grade II and III diffuse gliomas-both astrocytic and oligodendroglial—as well as secondary glioblastomas (GBM), but they are almost entirely absent from primary GBM [7, 9, 11]. As such, they appear to represent a defining early genomic lesion in the pathogenesis of diffuse

J. T. Huse $(\bowtie) \cdot$ K. Nafa $\cdot$ E. R. Kastenhuber

C. V. Hedvat - M. Ladanyi - M. K. Rosenblum

Department of Pathology, Memorial Sloan-Kettering Cancer Center, New York, NY 10065, USA

e-mail: husej@mskcc.org

\section{N. Shukla}

Department of Pediatrics, Memorial Sloan-Kettering Cancer Center, New York, NY 10065, USA

E. Lavi

Department of Pathology, New York Presbyterian Hospital, New York, NY, USA glioma variants exhibiting step-wise malignant evolution. Glioma-associated IDH mutations invariably involve active site arginine residues-R132 and R172 for IDH1 and IDH2, respectively_and, while their precise pathogenic mechanism remains unclear, they appear to promote the generation of the cancer-predisposing toxic metabolite, $R(-)$-2-hydroxyglutarate [6].

We assembled 12 cases of GTNI (Table 1) seen at the Memorial Hospital Department of Pathology, along with pertinent clinical information from the patients' medical records. To evaluate whether IDH1 and IDH2 mutations were present in our sample set, we performed custom genotyping assays on the Sequenom platform $[1,2]$ and/or employed validated immunohistochemical staining (IHC) for the most common IDH mutation, IDH1 R132H [5]. We found that every tumor in our sample set (12/12) exhibited evidence of the IDH1 R132H mutation by either one or both of our assay methods (Fig. 1a-d), and concordant results were achieved for all cases screened by both Sequenom ${ }^{\circledR}$ and IHC (Table 1). Both glial and neuronal components exhibited immuno-expression of mutant IDH1 in all examined cases (Fig. 1d).

The primary significance of our findings lies in strengthening the pathogenic link between GTNIs and the diffuse glioma tumor group. Studies to date indicate that within primary brain tumors, IDH mutations are largely restricted to diffuse gliomas evolving via step-wise malignant evolution (i.e., diffuse astrocytomas, oligodendrogliomas, and oligoastrocytomas). Combined with the frequent p53 immunoreactivity and general absence of 1p/19q chromosomal co-deletions previously documented in this setting, a high incidence of IDH1 mutations would fundamentally ally GTNIs with the diffuse astrocytoma and $1 \mathrm{p} / 19 \mathrm{q}$-intact oligoastrocytoma group. Indeed, the $100 \%$ incidence of IDH mutation in our sample set is even 
Table 1 Cases included in GTNI study cohort listed with patient age at first diagnosis, sex, histopathological grade (Grade), Sequenom ${ }^{\circledR}$ genotyping result (Sequenom) and IHC for IDH1 R132H (R132H IHC)

\begin{tabular}{|c|c|c|c|c|c|}
\hline Case & Age & Sex & Grade & Sequenom & R132H IHC \\
\hline 1 & 70 & M & LG & $\mathrm{R} 132 \mathrm{H}$ & NA \\
\hline $2^{\mathrm{a}}$ & 40 & M & HG: MVP/NEC & $\mathrm{R} 132 \mathrm{H}$ & NA \\
\hline $3^{\mathrm{a}}$ & 57 & M & LG & $\mathrm{R} 132 \mathrm{H}$ & NA \\
\hline $4^{\mathrm{a}}$ & 56 & M & HG & $\mathrm{R} 132 \mathrm{H}$ & NA \\
\hline $5^{\mathrm{a}}$ & 40 & M & LG & $\mathrm{R} 132 \mathrm{H}$ & + \\
\hline $6^{\mathrm{a}}$ & 38 & M & LG & $\mathrm{R} 132 \mathrm{H}$ & + \\
\hline $7^{\mathrm{a}}$ & 47 & M & LG & $\mathrm{R} 132 \mathrm{H}$ & + \\
\hline 8 & 43 & $\mathrm{~F}$ & LG & $\mathrm{R} 132 \mathrm{H}$ & NA \\
\hline 9 & 40 & M & HG & NA & + \\
\hline $10^{\mathrm{a}}$ & 41 & M & LG & $\mathrm{R} 132 \mathrm{H}$ & + \\
\hline 11 & 53 & F & HG & NA & + \\
\hline 12 & 29 & $\mathrm{~F}$ & HG & $\mathrm{R} 132 \mathrm{H}$ & + \\
\hline
\end{tabular}

$M$ male, $F$ female, $L G$ low-grade, $H G$ high-grade, $M V P$ microvascular proliferation, $N E C$ necrosis, $R 132 H$ IDH1 R132H mutation

${ }^{\text {a }}$ Cases included in a previous study of $1 \mathrm{p} / 19 \mathrm{q}$ co-deletion in GTNI [3]

Fig. 1 GTNI is characterized by IDH1 R132H mutations. a A mutation-positive Sequenom ${ }^{\circledR}$ spectrum from a representative GTNI sample displays an additional extension product of different mass, due to the $\mathrm{G}$ to $\mathrm{A}$ point mutation.

Photomicrographs of a representative case of GTNI stained with $\mathrm{H} \& \mathrm{E}$ (b) and immunostained for synaptophysin (c) and IDH1 R132H (d). All micrographs were taken at $\times 400$ magnification and reflect the same high-power field. Note mutant IDH1 labeling within both the neuropil-like island at right as well as the synaptophysin-negative glial component

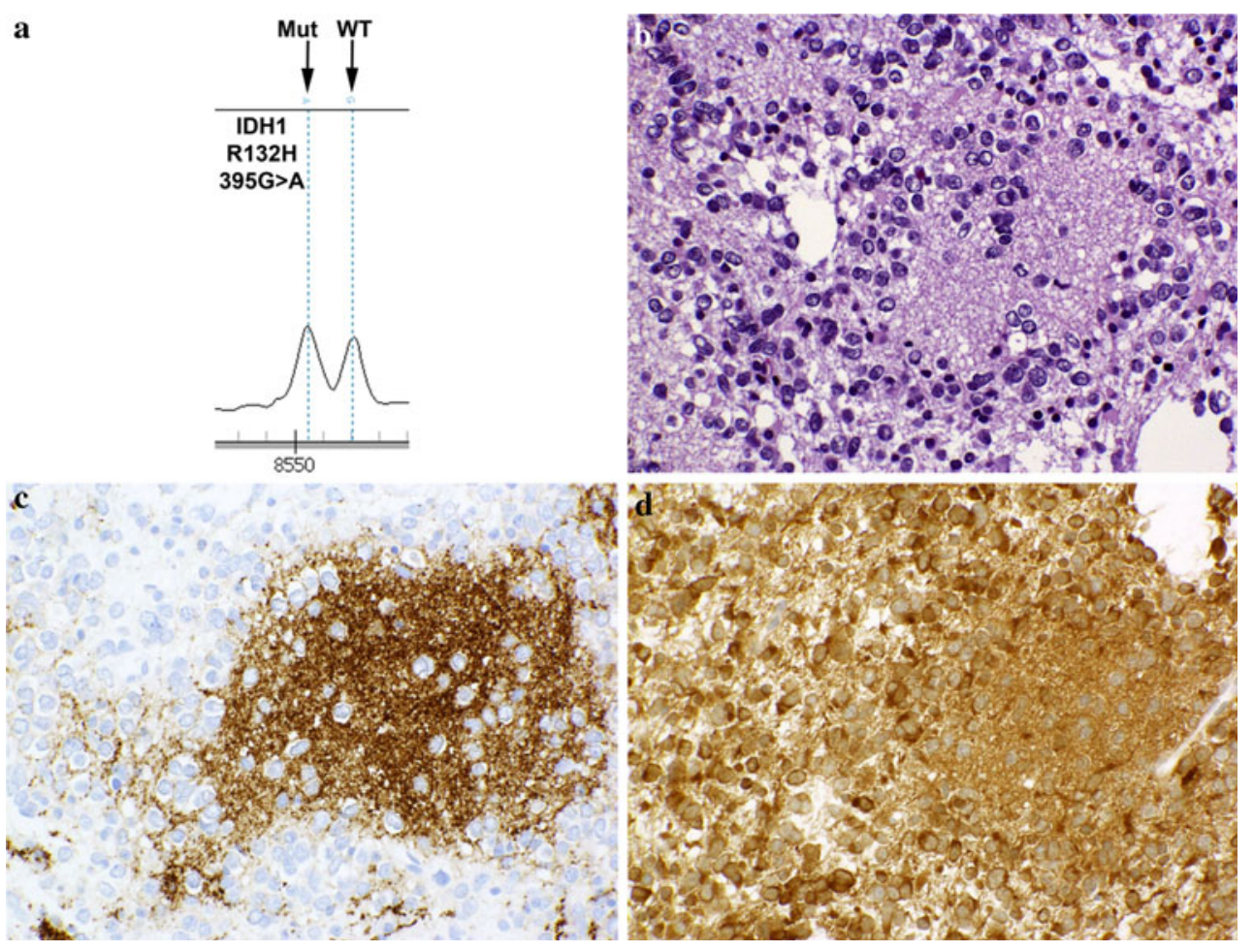

higher than that documented in diffuse astrocytoma so far $(\sim 80 \%)[7,11]$. As an aside, recent work has also identified IDH mutation as a prevalent feature of oligodendrogliomas with neurocytic differentiation [4], further emphasizing that focally prominent neuronal morphology falls well within the histopathological spectrum of diffuse gliomas in general. The invariable presence of the specific IDH1 R132H mutation in our GTNIs may represent an artifact of small sample number, but, nevertheless, it is striking. Whether other IDH1 or IDH2 mutational variants exist in GTNI and whether a genotypic restriction to IDH1 $\mathrm{R} 132 \mathrm{H}$ alone would have any functional significance remain unclear.

Acknowledgments We would like to thank Miriam Fayad for her assistance with immunohistochemical staining and Laetitia Borsu for 
assistance with Sequenom assays. The MSKCC Sequenom facility was supported by the Anbinder Fund.

Open Access This article is distributed under the terms of the Creative Commons Attribution Noncommercial License which permits any noncommercial use, distribution, and reproduction in any medium, provided the original author(s) and source are credited.

\section{References}

1. Amary MF, Bacsi K, Maggiani F, Damato S, Halai D, Berisha F, Pollock R, O’Donnell P, Grigoriadas A, Diss T, Eskandapour M, Presneau N, Hogendoorn PCW, Futreal A, Tirabosco R, Flanagan A (2011) IDH1 and IDH2 mutations are frequent events in central chondrosarcoma and central and periosteal chondromas but not in other mesenchymal tumours. J Pathol 224:334-343

2. Arcila M, Lau C, Nafa K, Ladanyi M (2011) Detection of KRAS and BRAF mutations in colorectal carcinoma roles for highsensitivity locked nucleic acid-PCR sequencing and broad-spectrum mass spectrometry genotyping. J Mol Diagn 13:64-73

3. Barbashina V, Salazar P, Ladanyi M, Rosenblum MK, Edgar MA (2007) Glioneuronal tumor with neuropil-like islands (GTNI): a report of 8 cases with chromosome $1 \mathrm{p} / 19 \mathrm{q}$ deletion analysis. Am J Surg Pathol 31:1196-1202

4. Capper D, Reuss D, Schittenhelm J, Hartmann C, Bremer J, Sahm F, Harter PN, Jeibmann A, von Deimling A (2011) Mutationspecific IDH1 antibody differentiates oligodendrogliomas and oligoastrocytomas from other brain tumors with oligodendroglioma-like morphology. Acta Neuropathol 121:241-252

5. Capper D, Zentgraf H, Balss J, Hartmann C, von Deimling A (2009) Monoclonal antibody specific for IDH1 R132H mutation. Acta Neuropathol 118:599-601
6. Dang L, White DW, Gross S, Bennett BD, Bittinger MA, Driggers EM, Fantin VR, Jang HG, Jin S, Keenan MC, Marks KM, Prins RM, Ward PS, Yen KE, Liau LM, Rabinowitz JD, Cantley LC, Thompson CB, Vander Heiden MG, Su SM (2009) Cancerassociated IDH1 mutations produce 2-hydroxyglutarate. Nature 462:739-744

7. Hartmann C, Meyer J, Balss J, Capper D, Mueller W, Christians A, Felsberg J, Wolter M, Mawrin C, Wick W, Weller M, HeroldMende C, Unterberg A, Jeuken JW, Wesseling P, Reifenberger G, von Deimling A (2009) Type and frequency of IDH1 and IDH2 mutations are related to astrocytic and oligodendroglial differentiation and age: a study of 1,010 diffuse gliomas. Acta Neuropathol 118:469-474

8. Keyvani K, Rickert CH, von Wild K, Paulus W (2001) Rosetted glioneuronal tumor: a case with proliferating neuronal nodules. Acta Neuropathol 101:525-528

9. Parsons DW, Jones S, Zhang X, Lin JC-H, Leary RJ, Angenendt P, Mankoo P, Carter H, Siu I-M, Gallia GL, Olivi A, McLendon R, Rasheed BA, Keir S, Nikolskaya T, Nikolsky Y, Busam DA, Tekleab H, Diaz LA Jr, Hartigan J, Smith DR, Strausberg RL, Marie SKN, Shinjo SMO, Yan H, Riggins GJ, Bigner DD, Karchin R, Papadopoulos N, Parmigiani G, Vogelstein B, Velculescu VE, Kinzler KW (2008) An integrated genomic analysis of human glioblastoma multiforme. Science 321:1807-1812

10. Teo JG, Gultekin SH, Bilsky M, Gutin P, Rosenblum MK (1999) A distinctive glioneuronal tumor of the adult cerebrum with neuropil-like (including "rosetted") islands: report of 4 cases. Am J Surg Pathol 23:502-510

11. Yan H, Parsons DW, Jin G, McLendon R, Rasheed BA, Yuan W, Kos I, Batinic-Haberle I, Jones S, Riggins GJ, Friedman H, Friedman A, Reardon D, Herndon J, Kinzler KW, Velculescu VE, Vogelstein B, Bigner DD (2009) IDH1 and IDH2 mutations in gliomas. N Engl J Med 360:765-773 